\title{
Digital Flipbook Media as a Media for Health Promotion in Youth: Research and Development
}

\author{
Marsiana Wibowo ${ }^{1}$ Erni Gustina², Suci Musvita $\mathrm{Ayu}^{3}$, Liena Sofiana ${ }^{4}$
}

\begin{tabular}{l} 
ARTICLE INFO \\
\hline Article History: \\
Received 06.04.2019 \\
Received in revised form \\
25.09 .2019 \\
Accepted \\
Available online 01.11 .2019
\end{tabular}

\begin{abstract}
Digital Flipbook is one of the multimedia-based media that is recommended to be developed because it can be accessed with gadgets or laptops. This research is Research and Development level 4, which is researching and testing in creating new products. Researchers developed the Digital Flip Book with the title Me: Teenagers and My Health. The purpose of developing this media is to increase the knowledge and attitudes of adolescents after reading the Digital Flipbook. This media design is a cover page, content (introduction to adolescent reproductive health situations, adolescent definitions, risk behaviors in adolescents which consists of understanding, impact, and prevention of premarital sex, violence, and early marriage), and improving adolescent reproductive health. The results of media development from media experts said that based on the assessment aspects, namely simplicity, cohesiveness, emphasis, balance, shape and color, the results obtained $91.67 \%$. The media to be used must be simple, easy to use on a gadget or laptop and balanced color combination. Material expert assesses $97.22 \%$. The language used in media must be easily understood, not a textbook, by the target of adolescents. Thus, a digital flipbook entitled "Me: Teenagers and My Health" is suitable for use in health promotion among adolescents and further field testing. This media has been tested on target, with the result that knowledge is good as much as $51.9 \%$ and a positive attitude as much as $59 \%$. Thus, the media has been used. However This process affects the output of learning using the application as a medium for health promotion for adolescents.
\end{abstract}

C IJERE. All rights reserved

Keywords:

Adolescents, digital flipbook, reproductive health

(a)

\section{INTRODUCTION}

Adolescence is a very extraordinary experience. Various impulses arise from within to enrich life experiences. The action of trying new things has pushed teenagers trapped in risky behaviors, such as smoking, drinking alcohol, premarital sex, drug consumption, and dating violence. The exposure of adolescents to pornography shows and attitudes that support premarital sex is a strong predictor for adolescents to display premarital sex. Therefore, efforts are needed to increase adolescent resilience in avoiding pressure to have premarital sex (Yuni, Adi, Siswanto, Wilopo, \& Hakimi, 2013). A factor influencing adolescents to stop doing risky behavior is increasing adolescents' understanding of the negative impact of risky behavior (Ayu, Wibowo, \& Sofiana, 2019; Karagoz, 2016).

Teenagers use the media to find the information which they don't know. The media has multiple meanings, both limited and broad. Internet-based media is known as new media while old media is noninternet based media (Parvanta, Nelson, Parvanta, \& Harner, 2011). The development of the media is very influential in today's youth behavior. Media with the internet is a medium that is highly accessible and valuable for young people to access a range of health issues. Interventions with the media have an impact on changes in adolescent behavior. Social media that contains text messages can increase adolescent knowledge about health, for example about the sexually transmitted disease (Jones, Eathington, Baldwin, \& Sipsma, 2014). Rural schools also felt the effects of modernization. Learning using eBooks results in higher effectiveness than printed books (Budi Santoso, Siswandari, \& Sawiji, 2018). Flipbook is a visual media that contains various information. This visual shaped media can be used as multimedia by adding music and video links in it. The flipbook can significantly improve the assessment of learning outcomes (Pornamasari, 2017). Student achievement (Wahyuliani, 2016) using flipbook maker assisted learning modules have been better-compared student achievement using conventional learning module. Multimedia-based flipbooks are recommended to be developed because this multimedia can be accessed with gadgets and laptops.

\footnotetext{
${ }^{1}$ marsiana.wibowo@ikm.uad.ac.id, Universitas Ahmad Dahlan, https://orcid.org/0000-0003-1990-6016 2 erni.gustina@ikm.uad.ac.id, Universitas Ahmad Dahlan, https://orcid.org/0000-0001-9334-4774

${ }^{3}$ https://orcid.org/0000-0002-2788-3961

${ }^{4}$ https://orcid.org/0000-0003-0424-2659
} 


\section{Situation of the Problem}

In this study, Digital Flipbook has been developed with the theme of adolescent health. In this study, researchers used technology to campaign for adolescent health because digital media has become the daily routine of the digital generation, namely teenagers (Dunlop, Freeman, \& Jones, 2016). Nearly all adolescents have digital devices, therefore adolescent health interventions must be adapted to the way teenagers navigate health and digital information and the health challenges that concern them most (Wartella, Rideout, Montague, Beaudoin-Ryan, \& Lauricella, 2016). Indonesia has various issues regarding adolescent reproductive health, especially risk behaviors that affect adolescent health. Teenagers need access to information that is accurate and in accordance with their development in adolescent reproductive health in order to increase their awareness of self-health.

\section{Aim of the Study}

The purpose of this research is to create a digital flipbook entitled "Me: Youth and My Health" that deserves to be published to adolescents as a target. Does this study raise the question: (1) how is the material feasibility in creating a digital flipbook? (2) How is the feasibility of the media in creating digital flipbooks (3) how is the student's knowledge before and after using a digital flipbook?

\section{METHOD}

This is level 4 Research and Development (R \& D), which is researching and testing in creating new products. The researcher developed a digital flipbook about adolescent behavior and health. The researcher involved two experts to assess the feasibility of the book, namely media and material experts. Researchers also consider the assessment of adolescents who are the target of this media in book eligibility. The product feasibility test in this study consisted of external validation and internal validation. Internal validation is the feasibility test with the assessment of experts, consisting of a media expert and a material expert. While internal testing is carried out with limited field testing, they are adolescents. The digital flipbook contains risk behaviors that affect health, videlicet premarital sex, violence, and early marriage.

\section{Material}

The process of developing the digital flipbook begans with a literature study of the material for risk behavior in adolescents which has an impact on health sourced from textbooks and experts in their fields. Information collected in the form of premarital sex behavior, violence, and early marriage that has an impact on health as well as how preventive measures, appropriate designs for teenagers, materials used in producing digital flipbooks, and production prices. The next step was to create a storyboard and page concept per page. Every information in the digital flipbook is illustrated with images to make it more interesting. Digital flipbooks that have been produced have been tested for their suitability with material and media experts with instruments prepared by researchers.

The researcher prepared 3 instruments, the first one was a questionnaire for media experts, the second for maternal experts, and the last for teenagers. The prepared research instrument was adjusted to the stages of data collection, namely design validation (internal validation) and limited trials. Instrument design validation is a questionnaire. The material feasibility measurement questionnaire consists of closed answer statements consisting of indicators of the suitability of the format, content, and language of Digital flipbook and questions with calm open answers to expert comments on the media. The digital flipbook media feasibility measurement questionnaire consists of closed answer statements consisting of indicators of simplicity, cohesiveness, emphasis, balance, shape and color from Digital flipbook and questions with calm open answers to expert comments on the media. The researcher revised the digital flipbook based on expert judgment and comments so that there was nothing else to revise. Thus, digital flipbook media can be tested on limited targets. The "limited trial" instrument uses a questionnaire to measure the functioning of the media in increasing adolescent knowledge and attitudes about premarital sex, violence and early marriage. The number of limited trial respondents is 27 students from one of the senior high schools in Yogyakarta, Indonesia. The targets of this test group were teenagers aged 17-18 years, both men and women.

\section{Data Analyses}

The design validation questionnaire on media and material experts uses a Likert scale with four choices of answers, namely very poorly given a value of 1 , poorly given a value of 2 , both given a value of 3 , 
and very well given a value of 4 . The total value of the answer is then percentage (Arikunto in (Hastuti \& Rohman, 2017)) . This percentage illustrates the feasibility of digital flipbooks in terms of media and material, media eligibility criteria explained in table 1.

Table 1. Media Eligibility Criteria

\begin{tabular}{ccc}
\hline Scale & Validation Level & Information \\
\hline $85.01 \%-100 \%$ & Very valid & No revision needed \\
\hline $70.01 \%-85 \%$ & Quite valid & Need a small revision \\
\hline $50.01 \%-70 \%$ & Less valid & Need major revision \\
\hline $1 \%-50 \%$ & Invalid & May not be used
\end{tabular}

Questionnaire lattices from the expert material assessment are the assessment of the media format, the content of the media, and the language used. While the media expert assessment questionnaire grid is an assessment of simplicity (easy to run on a pc/cell phone, can work well, can be operated without special experts or players, easy maintenance), cohesiveness (symbols, lines, colors are clearly visible and have continuity so that able to explain content), emphasis (unique and current creative ideas and ideas), balance (the balance of the use of images, writing, size with content), and shape (animation is clear, attractive, and easy to operate independently).

External validation in measuring the functioning of the media in increasing knowledge and attitudes using questionnaires. The knowledge questionnaire provides two answer choices, namely yes and no, while the attitude questionnaire provides five choices of answers, which are very agreed, agree, neutral, disagree, and strongly disagree. Quantitative data analysis uses descriptive analysis, namely calculating the percentage of answers. Qualitative data obtained from the contents of open comments from experts. This data is analyzed qualitatively.

\section{FINDINGS}

The results of the study are explained in 3 stages:

1. Storyboards and Picture Illustrations

The first step in creating a Digital flipbook is to create a storyboard. Sourced from a literature study, researchers have compiled the contents of the book. The contents of this book are then illustrated in the picture (adolescents and situations). The illustrations that have been made in this stage are still in the form of sketches. These results are then discussed again for the suitability of the contents and illustrations, as well as the provision of color. The result at this stage is an A5 size digital flipbook design, consisting of a cover page and contents. The cover page reads the title "Me: Teenagers and My Health", while the contents of the book consists of 20 pages, namely a table of contents, an introduction to the situation of adolescents, the definition of adolescents, risky behavior due to promiscuity such as premarital sex, violence and early marriage which includes understanding, impact, and prevention efforts. This digital flipbook is produced to be read offline and in the form of software applications.

2. Internal validation

a. Media Expert

The results of the expert material assessment are listed in table 2.

Tabel 2. Media Expert Result Validation

\begin{tabular}{lcl}
\hline \multicolumn{1}{c}{ Aspek } & Persentase (\%) & \multicolumn{1}{c}{ Keterangan } \\
\hline Simplicity & 100 & No revision needed \\
Cohesiveness & 75 & Needs a small revision \\
Emphasis & 100 & No revision needed \\
Balance & 75 & Needs a small revision \\
Form & 75 & Needs a small revision \\
Color & 100 & No revision needed \\
Overall Aspects & 91,67 & No revision needed \\
\hline
\end{tabular}

Based on the results of the assessment of media experts, there are three aspects that require minor revisions, namely aspects of cohesiveness, balance, and form. However, overall aspects do not need to be revised. Little input provided by media experts is about the appearance of color between the backgrounds of the page with the color of the writing. Both must have a contrasting color so that 
it reads well, both on smartphones and on laptops. The focus of the improvement is on pages 5, 14, and 15 on the media. However, this input has been improved.

Based on the process of creating a digital flipbook media for teenagers, things to note about the media are 1) Simplicity: a) Media must be easy to operate, both on a laptop or smartphone. If so, the target will be easy to access this educational media. b) The media if run can work well. c) Easy media operation, no expert needed d) Easy media maintenance b) Integration: symbols, lines, and colors used must be clearly visible and continuous that describe the contents of the media c) Emphasis: pouring creative ideas, unique, and the latest $\mathrm{d}$ ) Balance: there must be a balance of images, material content, the size of the writing with the media e) Shape: animation displayed by the media must be clear, attractive, and easily operated by the target independently f) Color: attractive color visuals, color selection clear, the text uses a contrasting color. The size, shape, and color of the letters are easy to read and the selection of images attracts attention.

b. Material Expert

The results of the expert material assessment are listed in table 3.

Table 3. Material Expert Result Validation

\begin{tabular}{lccl}
\hline \multicolumn{1}{c}{ Aspek } & Persentase Tahap 1 (\%) & Persentase Tahap 2 (\%) & Keterangan Hasil Akhir \\
\hline Format & 75 & 100 & No revision needed \\
Content & 87,5 & 93,75 & No revision needed \\
Language & 75 & 100 & No revision needed \\
Overall Contents & 80,6 & 97,22 & No revision needed \\
\hline
\end{tabular}

Based on the results of the review from the material experts stated that the first stage digital flipbook material needs to be revised slightly. Minor revisions such as the addition of preface related to adolescent issues related to health, packaging words using popular words, more operational and practical, illustrating images for psychological effects, adding religious content, adding preface from premarital sex to violence, the definition of violence should not be too long and the addition of images to help teenage understanding. In the second stage of an expert material assessment, the expert gave the assessment does not need to be revised because of the improvements that have been made with an overall assessment of $97.22 \%$.

Based on the process of creating material in this media, the things that need to be considered in compiling material are the format (the material is arranged coherently according to the chronology of the incident, the suitability of the image with the content, the picture and the contents are easy to understand and interesting), the content (must be according to the learning objectives, is material current and comprehensive, there is preface to the introduction of the material, using pictures that illustrate what is conveyed, the addition of religious content related to adolescent health), language (use language that is popular for teenagers, language is not stiff, practical, does not use long sentences, short and clear sentences, not boring).

c. Limited field test

The result of limited field test are listed in table 4.

Table 4. Results of Distribution of Knowledge and Attitudes Percentage and Attitudes Before and After Giving Digital flipbook to High School 5 Yogyakarta Students

\begin{tabular}{lcc}
\hline \multicolumn{1}{c}{ Variabel } & \multicolumn{2}{c}{ Percentage (\%) } \\
\hline Knowledge & Before & After \\
Good & & \\
Not good & 63 & 51,9 \\
Sikap & 37 & 48,1 \\
Possitive & & \\
Negative & 51,9 & 51,9 \\
\hline
\end{tabular}


Based on these results, the provision of digital flipbooks has not been able to increase knowledge and change students' attitudes. Researchers need to evaluate the implementation in providing this digital flipbook.

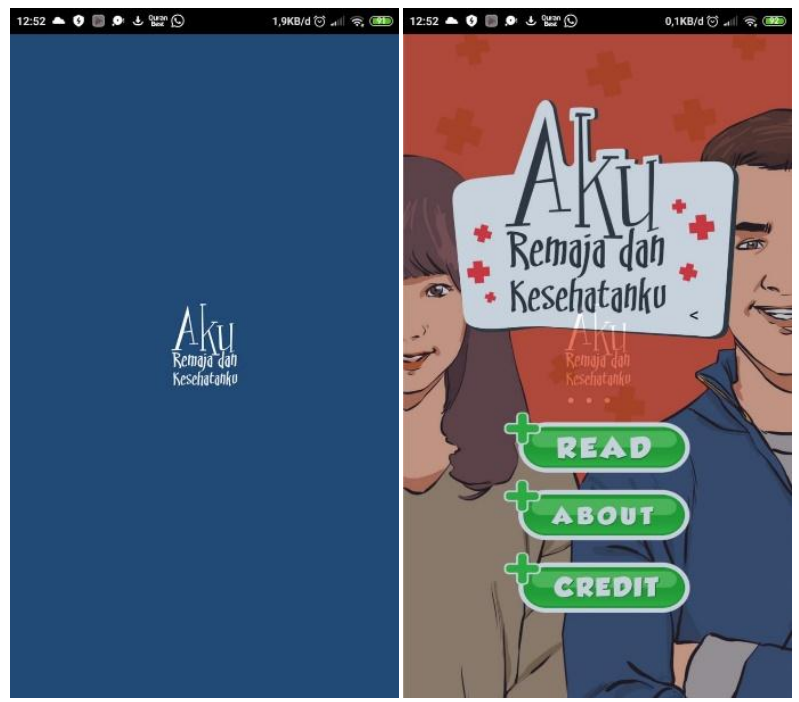

Figure 1. Digital front view flipbook in the application

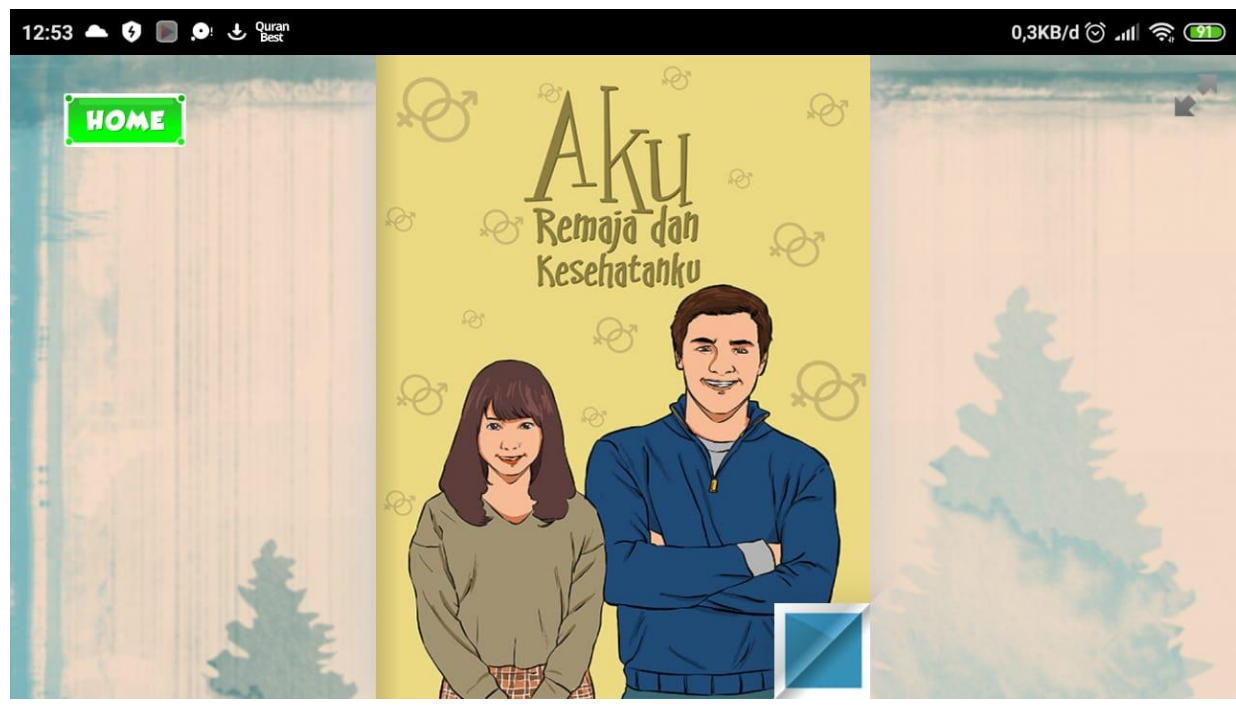

Figure 2. Cover of Digital FlipBook

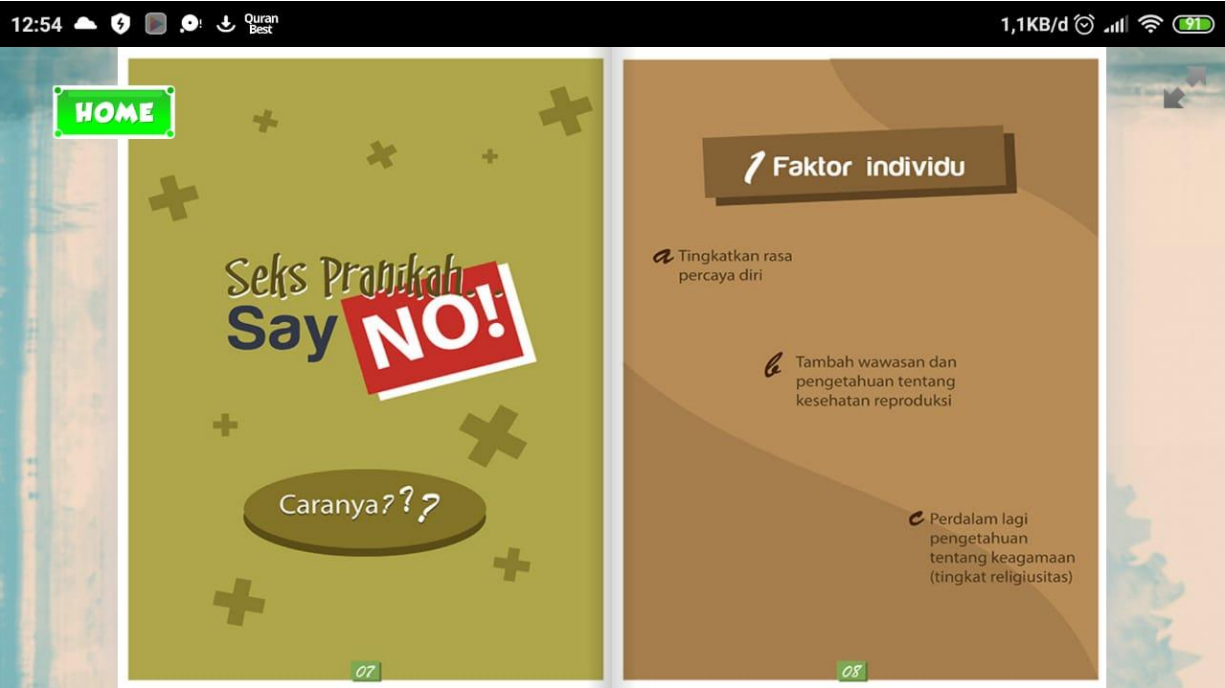

Figure 3. Part Of The Flipbook Digital Page 


\section{RESULT, DISCUSSION, AND SUGGESTIONS}

Teenagers are figures that are known to be very complex with health problems. Much has been published about risk behaviors carried out by adolescents. The government can provide more precise and accurate basic information about preventing risk behaviors, including social and psychological influences in their lives (Lestary \& Sugiharti, 2011). Besides, it is necessary to convey reproductive health education and healthy life skills through mass media. A campaign is needed through media advertising and easy access to information for adolescents, both men and women, in suppressing early marriages which have an impact on adolescent reproductive health (Berliana et al., 2018). Knowledgeable women will not marry as early as women who have limited access to information media (Rumble, Peterman, Irdiana, Triyana, \& Minnick, 2018). In the Digital Age, it is necessary for adolescents to socialize the dangers of free sex and provide education about the dangers of sex without legal marriage(Purnomo \& Winarso, 2019).

Booklet, a small printed booklet used for sharing information, including health, has been able to demonstrate its function in increasing knowledge of reproductive health (Gard et al., 2011). This booklet can be used as an eBook or converted to a digital flipbook appearance to make it more interesting. The study created a digital flipbook that targets adolescents to increase their knowledge of adolescent risk behaviors that affect their health. Flipbook media is easy and suitable media for learning (Hastuti \& Rohman, 2017). The ease of user access to a media is influenced by the user's perception of the usefulness and ease of use of information technology, so this becomes a measure of technology acceptance, such as digital flipbooks. Ease of use will have a positive impact on its utilization (Kuswandari, Suryoputro, \& Nugraha, 2014). The development of electronically packaged modules allows the target to learn independently using a computer or other electronic reading device. The operation of Flip Books is very easy to understand and increases target motivation (Wijayanto \& Saifuddin Zuhri, 2014).

Teenagers are a very interesting period because of the complexity of life experiences in the transition to adulthood. Health service providers, educators, and related parties should take steps to reduce risk factors and increase protective factors in adolescents (Resnick et al., 1997). Development of material around adolescent reproductive health has been developed. In this condition, there is a great opportunity to develop an effective component of adolescent health interventions, tailored to the needs of the target (Guse et al., 2012). In this study, a digital flipbook has been developed on the topic of adolescent health. This media is organized based on the current situation experienced by adolescents, such as adolescent problems that severely hamper their productivity, such as premarital sexual behavior, violence, and early marriage. Dissemination of information through online media or social networks needs to be done to increase adolescent awareness about reproductive health and increase access to adolescent reproductive health care (Violita \& Hadi, 2019). Researchers arrange storyboards as the first step of the work. A very important job is compiling storyboards (Sugianto, Abdullah, Elvyanti, \& Muladi, 2015). Next, develop interesting media designs. This step is one step to developing effective media (Pornamasari, 2017). The development of this material also includes the selection of images that can represent the material presented. The results of this study result that the preparation of reproductive health material for adolescents needs to add religious content. Health promotion programs for adolescents must be developed by taking into account prevalent social, cultural, religious values in preventing active reproductive health behaviors (Djannah, 2017; Susanto et al., 2016). Monitoring the growth of adolescents needs to be done continuously, especially in improving their spiritual intelligence to suppress reproductive health behavior that is risky for adolescents (Simak, Fitriyani, \& Setiawan, 2019). Digital flipbooks developed by researchers use many colorful images that represent the material presented. Images are made to appeal to the audience because attractive images will add to the audience's interest and safety in the media and material presented (Setyawati \& Herlambang, 2015). The suitability of the material presented is one indicator of content assessment in the media (Fonda \& Sumargiyani, 2018). Input by material experts is to provide religious value about adolescent risk behavior. Assessment of the suitability of values, morality, and social is one indicator that needs to be included. Material experts also stated that the choice of words used was operational, popular, and practical. The use of language must be effective and efficient (brief and clear) (Fonda \& Sumargiyani, 2018).

The digital age offers huge opportunities like never before. Media use has become a daily routine (Dunlop et al., 2016). Electronic media has positive and great social and learning opportunities for teenagers. 
Technological developments such as mobile phones that are designed to be very visually appealing will add interest to young audiences and they will become intensive and competent users of new technology (DavidFerdon \& Hertz, 2007). New digital media for the promotion of sexual health is emerging. The new digital media has tremendous potential to support adolescent sexual health (Guse et al., 2012). Teenagers must be educated about how digital media marketing is so that they become media literate consumers (Dunlop et al., 2016). In this study, a digital flipbook has been developed with the theme of adolescent health. In this study, researchers used technology to campaign for adolescent health. Why digital technology? Because digital media has become the daily routine of the digital generation, namely teenagers (Dunlop et al., 2016). Almost all adolescents have digital devices, therefore adolescent health interventions must be adapted to the way teens navigate digital health information and the health challenges that concern them most (Wartella et al., 2016). Social media and text messaging have proven to be effective in increasing adolescent knowledge about STD prevention. These interventions also apply to influence behavior, such as screening/testing for STIs, sexual risk behavior, and transmission of STIs, but the evidence for their effects is weak (Jones et al., 2014). In this study, researchers developed Digital Book into an application. Researchers chose flipbooks because flipbooks were effectively able to increase adolescent knowledge about violence in adolescents (Widyastuti, Mumin, \& Yuliantisari, 2017). Therefore, the effectiveness is applied in this study. Flipbook media development must be easy to operate (Mulyadi, Wahyuni, \& Handayani, 2016). Based on the assessment of media experts, digital flipbooks that have been developed by researchers have ease in operation. In addition, the selected animation must also have an appeal to the audience so that the audience has the motivation to learn more (Mulyadi et al., 2016). Based on the assessment of media experts, the animation aspect has a value of $75 \%$ and visuals that include $100 \%$ color integration. The elements of music and animation are considered to be able to increase student motivation (Mulyadi et al., 2016). The distribution of digital flipbook media is easy and inexpensive. Media can be disseminated using social media like Facebook, Yahoo, Google, and Twitter. Thus, users can easily access the media anytime and anywhere (Mulyadi et al., 2016). From the results of the frequency distribution, we get a difference in the percentage of knowledge where before digital flipbooks were given, $63 \%$ teenagers had good knowledge but after being given a digital flipbook on the teenage knowledge variable decreased $(48.1 \%)$. There was a decrease in the knowledge variable before and after the provision of digital flip books due to the absence of monitoring to adolescents whether teenagers read the flipbooks provided, download and install tutorials on smartphones (gadgets) given to adolescents are not fully understood by teenagers. When data is collected at school, the media provided are still in the form of HTML. Media in the form of applications is easier to give to teenagers, for example using the share it application. The limitation of this study is the researcher allowed the target to read independently the digital flipbook which was then conducted a post-test several days later. The researcher did not ascertain whether the installed digital flipbook had been well read by teenagers. The researcher allowed the target to read independently the digital flipbook which was then conducted a post-test several days later. We suggest that future researchers use the application as a health promotion medium to prepare the application distribution process properly, and ensure that the application is installed and used by the target. This process affects the output of learning using the application as a medium for health promotion for adolescents.

The conclusion of this study are a) Based on the validation of material experts, the digital flipbook media with the title "Me: Youth and My Health" does not need revision, with a value of $97.22 \%$. This means that the media is appropriate to use b) Based on the validation of media experts, the digital flipbook media with the title "Me: Youth and My Health" does not need revision, with a value of $91.67 \%$. This means that the media is appropriate to use c) After accessing the media, the target of having good knowledge was $51.9 \%$ and a positive attitude of $51.9 \%$. 
Wibowo,M., Gustina,E., Ayu,S.M. \& Sofiana,L. (2019). Digital flipbook media as a media for health promotion in youth: Research and development. International Journal of Educational Research Review, Special Issue,725-733.

\section{REFERENCES}

Ayu, S. musvita, Wibowo, M., \& Sofiana, L. (2019). Phenomenological study of risky teenager behavior in vocational high school "a" in Yogyakarta. International Journal of Evaluation and Research in Education (IJERE), 8(3). https://doi.org/10.11591/IJERE.V8I3.20241.

Berliana, S. M., Kristinadewi, P. A. N., Rachmawati, P. D., Fauziningtyas, R., Efendi, F., \& Bushy, A. (2018). Determinants of early marriage among female adolescent in Indonesia. International Journal of Adolescent Medicine and Health. https://doi.org/10.1515/ijamh-2018-0054.

Budi Santoso, T. N., Siswandari, S., \& Sawiji, H. (2018). The Effectiveness of e-Book versus printed books in the rural schools in Indonesia at the modern learning era. International Journal of Educational Research Review, 3(4), 77-84. https://doi.org/10.24331/ijere.453512.

David-Ferdon, C., \& Hertz, M. F. (2007). Electronic media, violence, and adolescents: An emerging public health problem. Journal of Adolescent Health, 41(6 SUPPL.), 1-5. https://doi.org/10.1016/j.jadohealth.2007.08.020.

Djannah, S. N. (2017). The Adolescents Overview with healthy sexual behavior in the risky environment. International Journal of Evaluation and Research in Education (IJERE), 6(3), 221. https://doi.org/10.11591/ijere.v6i3.6040.

Dunlop, S., Freeman, B., \& Jones, S. C. (2016). Marketing to youth in the digital age: The promotion of unhealthy products and health promoting behaviours on social media. Media and Communication, 4(3), 35. https://doi.org/10.17645/mac.v4i3.522.

Fonda, A., \& Sumargiyani, S. (2018). The developing math electronic module with scientific approach using kvisoft flipbook maker pro for xi grade of senior high school students. Infinity Journal, 7(2), 109-122. https://doi.org/10.22460/infinity.v7i2.p109-122.

Gard, J. C., Kan, M. L., Jones, S. B., Williams, J. C., Evans, W. D., \& Davis, K. C. (2011). Organizational use of a media campaign booklet to encourage parent-child communication about waiting to have sex. Social Marketing Quarterly, 17(1), 91-107. https://doi.org/10.1080/15245004.2011.547143.

Guse, K., Levine, D., Martins, S., Lira, A., Gaarde, J., Westmorland, W., \& Gilliam, M. (2012). Interventions using new digital media to improve adolescent sexual health: A systematic review. Journal of Adolescent Health, 51(6), 535-543. https://doi.org/10.1016/j.jadohealth.2012.03.014.

Hastuti, U. S., \& Rohman, F. (2017). Pengembangan media flipbook pada materi. Jurnal Teori, Penelitian, Dan Pengembangan, 2(11), 1450-1455. Retrieved from http://journal.um.ac.id/index.php/jptpp/article/download/10156/4843.

Jones, K., Eathington, P., Baldwin, K., \& Sipsma, H. (2014). The impact of health education transmitted via social media or text messaging on adolescent and young adult risky sexual behavior. Sexually Transmitted Diseases, 41(7), 413-419. https://doi.org/10.1097/OLQ.0000000000000146.

Karagoz,S. (2016). Opinions and suggestions regarding various subjects on the educational guidance in the second constitutional era. Journal of Family, Counseling and Education,1(1),1-9.

Kuswandari, T. Y., Suryoputro, A., \& Nugraha, P. (2014). Pemanfaatan Buku Kesehatan dan Buku Info Remaja di Kabupaten Bondowoso. Jurnal Promosi Kesehatan Indonesia, 9(1), 104-115. Retrieved from https://ejournal.undip.ac.id/index.php/jpki/article/viewFile/12703/9522.

Lestary, H., \& Sugiharti. (2011). Perilaku Berisiko Remaja Di Indonesia Menurut Survey Kesehatan Reproduksi Remaja Indonesia ( Skrri ) Tahun 2007. Jurnal Kesehatan Reproduksi, 1(3), 136-144. Retrieved from http://ejournal.litbang.depkes.go.id/index.php/kespro/article/download/1389/696.

Mulyadi, D. U., Wahyuni, S., \& Handayani, R. D. (2016). Pengembangan Media Flash Flipbook Untuk Menıngkatkan Keterampilan Berfıkır Kreatıf Sıswa Dalam Pembelajaran Ipa Dı Smp. Jurnal Pembelajaran Fisika, 4(4), 296-301. Retrieved from https://jurnal.unej.ac.id/index.php/JPF/article/view/2728/2202.

Parvanta, C., Nelson, D., Parvanta, S., \& Harner, R. (2011). Essentials of public health communication (R. Riegelman, ed.). USA: Jones \& Bartlett Learning. 
Pornamasari, E. I. (2017). Pengembangan Modul peembelajaran Berbantu Flipbook maker dengan Model Pembelajaran Numbered Heads Together (NHT) Berbasis Teori Vygotsky Materi Pokok Relasi dan Fungsi. Jurnal Pendidikan Matematika, 1(1), 74-83. Retrieved from http://journal.upgris.ac.id/index.php/aksioma/article/viewFile/1412/1211.

Purnomo, H., \& Winarso, W. (2019). Sex education pattern for 12 years compulsory education age in digital era. SSRN Electronic Journal. https://doi.org/10.2139/ssrn.3431549.

Resnick, M. D., Bearman, P. S., Blum, R. W., Bauman, K. E., Harris, K. M., Jones, J., ... Udry, J. R. (1997). Protecting adolescents from harm: Finding from the national longitudinal study on adolescent health. Centers for Disease Control and Prevention, 278(10), 1-6. https://doi.org/10.1001/jama.1997.03550100049038.

Rumble, L., Peterman, A., Irdiana, N., Triyana, M., \& Minnick, E. (2018). An empirical exploration of female child marriage determinants in Indonesia. BMC Public Health, 18(1). https://doi.org/10.1186/s12889-0185313-0.

Setyawati, V. A. V., \& Herlambang, B. A. (2015). Model edukasi gizi berbasis e-booklet untuk meningkatkan pengetahuan gizi ibu balita. Jurnal Informatika Upgris, 1(1 Juni), 86-94. https://doi.org/10.26877/JIU.V1I1 JUNI.810.

Simak, V. F., Fitriyani, P., \& Setiawan, A. (2019). The Relationships between Risky sexual practices and spiritual intelligence of adolescents in Indonesia. Comprehensive Child and Adolescent Nursing, 42(sup1), 73-81. https://doi.org/10.1080/24694193.2019.1578298.

Sugianto, D., Abdullah, A. G., Elvyanti, S., \& Muladi, Y. (2015). Modul virtual: Multimedia flipbook dasar teknik digital. Invotec, IX(2), 101-116. Retrieved from http://ejournal.upi.edu/index.php/invotec/article/download/4860/3399.

Susanto, T., Rahmawati, I., Wuryaningsih, E. W., Saito, R., Syahrul, Kimura, R., ... Sugama, J. (2016). Prevalence of factors related to active reproductive health behavior: a cross-sectional study Indonesian adolescent. Epidemiology and Health, 38, e2016041. https://doi.org/10.4178/epih.e2016041.

Violita, F., \& Hadi, E. N. (2019). Determinants of adolescent reproductive health service utilization by senior high school students in Makassar, Indonesia. BMC Public Health, 19(1), 1-7. https://doi.org/10.1186/s12889-019-6587-6.

Wahyuliani, Y. (2016). Efektıvitas penggunaan media pembelajaran flip book terhadap peningkatan hasil belajar siswa pada mata pelajaran pai dan budi pekerti di sma negeri 4 bandung. Tarbawy, 3(1), 22-36. Retrieved from http://ejournal.upi.edu/index.php/tarbawy/article/download/3457/2443.

Wartella, E., Rideout, V., Montague, H., Beaudoin-Ryan, L., \& Lauricella, A. (2016). Teens, health and technology: A national survey. Media and Communication, 4(3), 13. https://doi.org/10.17645/mac.v4i3.515.

Widyastuti, Y., Mumin, K. A., \& Yuliantisari. (2017). The Optimalization of Adolescent Health in The Era of SDGs. Retrieved from http://eprints.poltekkesjogja.ac.id/316/1/Naskah 20. Yani Widyastuti proceeding book.pdf

Wijayanto, \& Saifuddin Zuhri, M. (2014). Pengembangan E-modul berbasis flip book maker dengan model project based learning untuk mengembangkan kemampuan pemecahan masalah matematika. Prosiding Mathematics and Sciences Forum, 625-628. Retrieved from http://prosiding.upgris.ac.id/index.php/masif2014/masif2014/paper/viewFile/487/436.

Yuni, K., Adi, R., Siswanto, U., Wilopo, A., \& Hakimi, M. (2013). Premarital sexual inisiation of adolescence. Kesehatan Masyarakat Nasional, 7(11), 180-185. Retrieved from http://journal.fkm.ui.ac.id/kesmas/article/download/53/54. 